\title{
Determination of Soluble/Exchangeable Metals in Peri-urban Farmland (Ribeira dos Covões) of Central Portugal
}

\author{
Ryunosuke Kikuchi ${ }^{1}$, Carla S. S. Ferreira ${ }^{2}$, Fábio L. P. Viela ${ }^{3}$ \\ ${ }^{1}$ Faculty of Science \& Technology, Ryukoku University \\ Seta, Yokotani 1-5, Otsu, Japan \\ kikuchi@rins.ryukoku.ac.jp \\ ${ }^{2}$ Centro de Recursos Naturais, Ambiente e Sociedade, Escola Superior Agrária de Coimbra \\ Bencanta, Coimbra, Portugal \\ cferreira@esac.pt \\ ${ }^{3}$ Faculdade de Ciências, Universidade Agostinho Neto \\ Av. 7 de Fevereiro, Luanda, Angola \\ fabioviela1988@gmail.com
}

\begin{abstract}
Heavy metal contamination of soil is widespread, and there is a potential risk of transferring toxic metals to agricultural crops, animals and humans. The total heavy metals content can indicate the extent of contamination, but this measure is not usually an accurate indication of the phyto-toxicity; therefore, a number of recent studies have investigated the bioavailable heavy metal fractions in soils and evaluated the phyto-toxic risks for humans. Soluble and exchangeable forms of metals in the soil are the fractions available for plants. The main purpose of the present study is to quantify the total and soluble/exchangeable fractions of heavy metals $(\mathrm{Pb}, \mathrm{Cr}, \mathrm{Cu}$ and $\mathrm{Zn}$ ) in soils of peri-urban farmland in Portugal (Ribeira dos Covões). The results show that the total heavy metals content is greater than the soluble/exchangeable content, but no clear correlations were recorded: $\mathrm{Pb}-70.8 \mathrm{mg} / \mathrm{kg} \mathrm{vs.} 16.7 \mathrm{mg} / \mathrm{kg}, \mathrm{Cr}-25.0 \mathrm{mg} / \mathrm{kg}$ vs. 0.0 $\mathrm{mg} / \mathrm{kg}, \mathrm{Zn}-383.3 \mathrm{mg} / \mathrm{kg}$ vs. $0.0 \mathrm{mg} / \mathrm{kg}, \mathrm{Cu}-183.3 \mathrm{mg} / \mathrm{kg}$ vs. $0.0 \mathrm{mg} / \mathrm{kg}$ in a horticultural garden (site 10 ), and; $\mathrm{Pb}-270.8 \mathrm{mg} / \mathrm{kg}$ vs. $79.0 \mathrm{mg} / \mathrm{kg}, \mathrm{Cr}-25.0 \mathrm{mg} / \mathrm{kg}$ vs. $0.0 \mathrm{mg} / \mathrm{kg}, \mathrm{Zn}-12.5 \mathrm{mg} / \mathrm{kg}$ vs. $0.0 \mathrm{mg} / \mathrm{kg}, \mathrm{Cu}-33.3 \mathrm{mg} / \mathrm{kg}$ vs. $29.2 \mathrm{mg} / \mathrm{kg}$ in a backyard (site 18 ). It is possible that the use of a single extraction procedure, in the laboratory, may not provide a proper assessment of heavy metal forms, and it is therefore advisable to combine different extraction methods in order to correctly perform a risk-based evaluation.
\end{abstract}

Keywords: Bioavailable Fraction, Farmland, Heavy Metal, Peri-Urban, Portugal.

\section{Introduction}

Heavy metal contamination of soils is widespread and there is a risk of transfer of toxic and available metals to agricultural crops, animals and humans [1]. Heavy metals can induce toxicity in wildlife if the level in the soil reaches critical concentrations; accumulation in above-ground tissues of plants can also result in an increase of metal accumulation in topsoil, via leaf deposition, or can create an exposure pathway for metal introduction into the food chain [2]. Two main sources of heavy metals in soils can be considered: the natural pedo-geochemical background, which represents the heavy metal concentration inherited from the parent rock [3] and anthropogenic contamination, which can be directed via wastes [4], compost [5], or sewage sludge [6] or may diffuse via aerosol deposition [7].

The total heavy metal contents can indicate the extent of contamination, but is not usually an accurate indication of the phyto-toxicity [8 \& 9]. Many recent studies investigated the bioavailable heavy metal fractions of mine soils [8 \& 9] and evaluated the phyto-toxic risk for human receptors. Bioavailability is the proportion of total metals that are available for incorporation into biota (bioaccumulation). Total metal concentrations do not necessarily correspond with metal bioavailability [10]. However, the determination of heavy metal fractions is a more complex task than the determination of the total contents of heavy metals [11].

Several analytical methods have been used to quantify heavy metals in the soil; for example, the soil extraction with strong acids is commonly carried out to assess total heavy metals, and X-ray fluorescence spectrometry is used to determine the content of total elements (review in [12]). Soluble and exchangeable forms of metals in the soil are the fractions available 
for plants, and it is known that extraction with ammonium acetate $\left(\mathrm{NH}_{4} \mathrm{CH}_{3} \mathrm{CO}_{2}\right)$ is one method for estimating the soluble and rapidly exchangeable pools of elements in the soil (cf. [12 \& 13]).

The main purpose of the present study is to quantify the soluble/exchangeable portion of metals in peri-urban Portuguese farmland (Ribeira dos Covões) by means of the ammonium acetate extraction.

\section{Peri-Urban Areas}

Peri-urban areas are defined by the structure resulting from the process of pre-urbanisation [14], and comprise the landscape interface between urban and rural areas. A peri-urban area attracts new types of housing, transport infrastructures and multifunctional agriculture, with a wide range of recreation sites and ecosystem services. Urban development, by far the most rapidly expanding land use type in Europe (see Fig. 1 right), puts peri-urban areas under particular pressure: the growth of built development in peri-urban areas is likely to be up to four times as fast as in urban areas [15]. Europeanwide projections of built development in peri-urban areas estimate 1.4-2.5\% per annum, and the total built development in peri-urban areas will double between 2040-2060 [15].

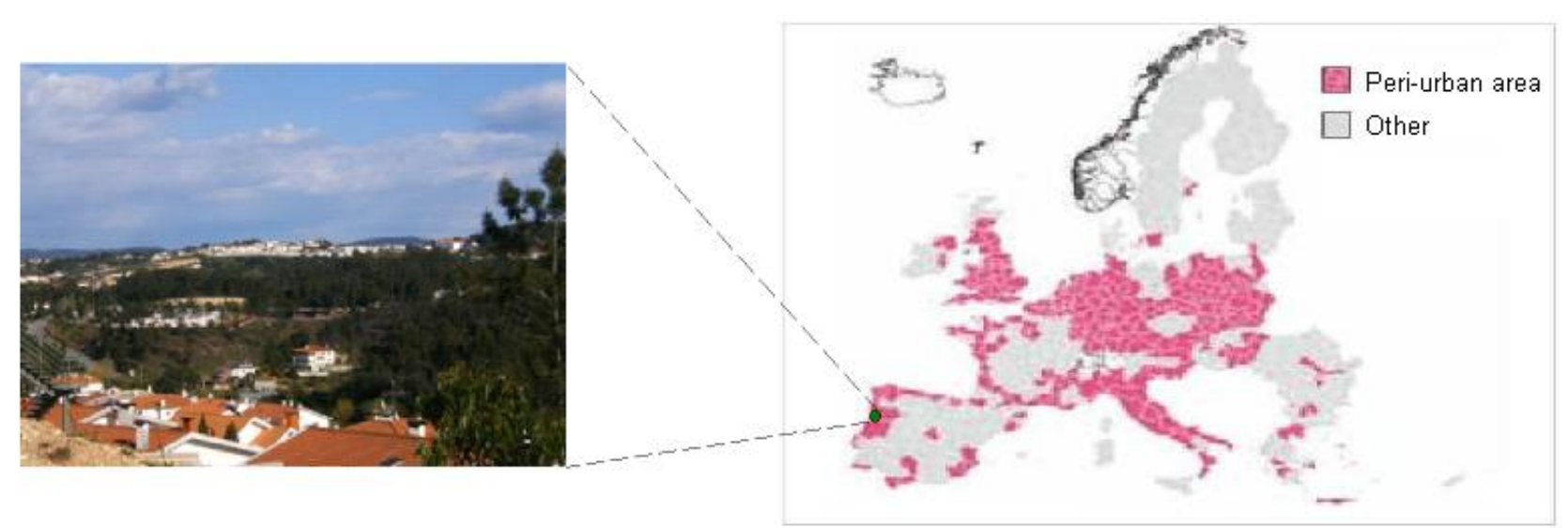

Fig. 1: Distribution of peri-urban areas in Europe (redrawn form [15]) (right) and study site (Ribeira dos Covões) in Portugal (left).

\section{Study Site}

The study was carried out in the peri-urban Ribeira dos Covões catchment $\left(8^{\circ} 27^{\prime} \mathrm{W}\right.$ and $\left.40^{\circ} 13^{\prime} \mathrm{N}\right)$, located $3 \mathrm{~km}$ northwest of Coimbra, the largest city in central Portugal.

The catchment (see Fig.1 left) is $6.2 \mathrm{~km}^{2}$, aligned north-south, with altimetry ranging from 34 to $205 \mathrm{~m}$ a.s.1. The area has a Mediterranean climate, with a mean annual temperature of $15^{\circ} \mathrm{C}$ and an average annual rainfall of $892 \mathrm{~mm}$ [16]. Between 1958 and 2007, the urban area expanded from 6\% to $32 \%$ and woodland expanded from $44 \%$ to $64 \%$, at the expense of agricultural land, which showed a marked decrease from $48 \%$ to $4 \%$.

The catchment is underlain by sandstone (57\%) and limestone (43\%). Soils developed on sandstone are classified as Fluvisols and Podsols, whereas in limestone they are Leptic Cambisols.

The woodland area consists mainly of Eucalyptus globulus Labill. plantations (55\%), but with some mixed stands of eucalypt and pine (29\%), scrubland (15\%) and relict oak woodland composed of Quercus roburL., Q. faginea broteroi and $Q$. suber $L$. trees $(1 \%)$. Generally, eucalypt plantations occur on sandstone. The agriculture areas are mainly comprised of backyards, used for family consumption as a complementary income, and by relatively small pasture fields and few remaining olive groves.

\section{Methods}

Twenty four soil surface samples $(0-2 \mathrm{~cm})$ were collected in distinct farmland areas within Ribeira dos Covões on $16 / 08 / 2017$. The collected samples were dried at room temperature. The dry samples were disaggregated using a mortar and pestle and put through a sieve with a $2 \mathrm{~mm}$ grid. After this sieving operation, metal elements were extracted from the pretreated samples using two different methods - (i) a $1.7 \mathrm{~g}$ sample was mixed with $50 \mathrm{ml}$ of $1 \mathrm{M}$ ammonium acetate and shaken for 2 hours [17]. Then, the extracted metals from the sample were filtrated, and they are denoted as bioavailable 
fractions in this paper; and (ii) a $1.7 \mathrm{~g}$ sample was mixed with $10 \mathrm{ml}$ concentrated $\mathrm{HNO}_{3}$ and heated. Furthermore, $20 \mathrm{ml}$ $\mathrm{HCLO}_{4}$ was added to this mixture and again heated [18]. After cooling, $20 \mathrm{ml} \mathrm{HCl}$ was used as the final reflux acid for chemical analysis. Then, the extracted metals were filtered, and they are denoted as the total metal portion in this paper. The following elements were simultaneously determined by inductively coupled plasma spectrometry (Perkin Elmer, Optima $5300 \mathrm{DV})-\mathrm{Cu}, \mathrm{Pb}, \mathrm{Cr}$ and $\mathrm{Zn}$.

\section{Results and Discussion}

The bioavailable fraction of metals represents a relatively low portion of the total heavy metals. For example, less than $0.01 \%$ of the total content of nitrogen generally exists in plant-available form [19]. As stated above, analytical attention was given to quantifying the element content that would be available for plant uptake. The amounts of elements extracted with ammonium acetate can be mainly considered plant-available [20]. Given the large number of sampling sites and the limited space, this paper presents data from only two representative sites (Fig. 2): site 10, a typical horticulture garden, and site 18, representative of local backyards. As expected, the obtained results prove that the total element content is much different from the plant-available content.

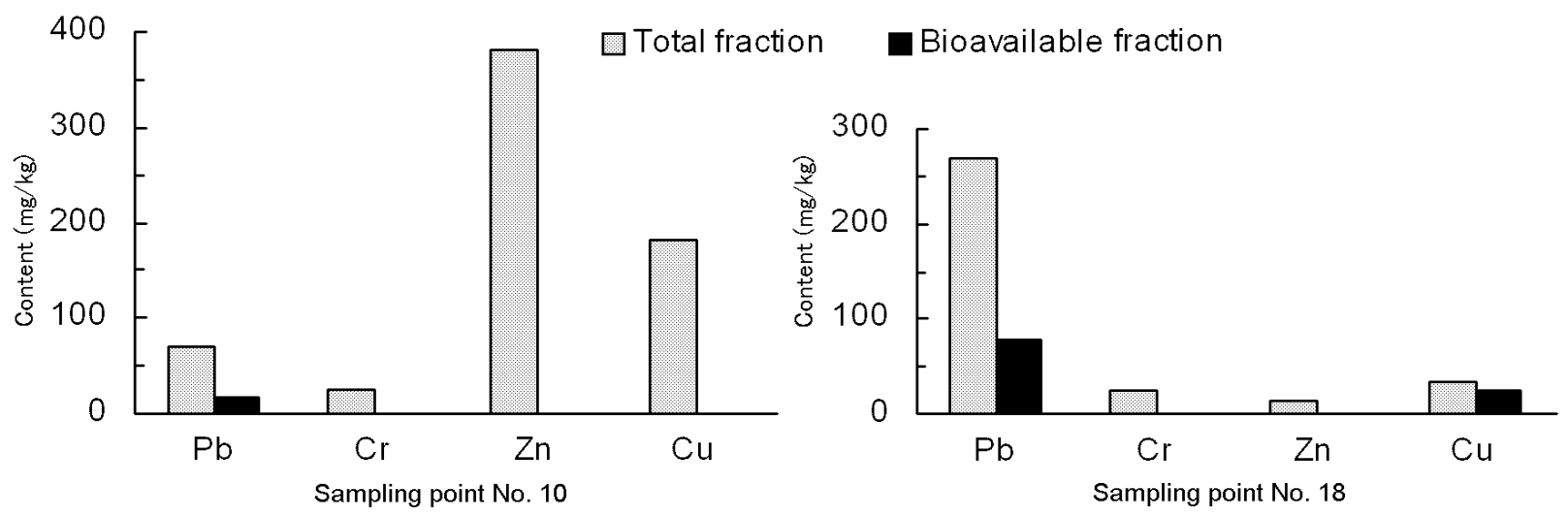

Fig. 2: Metal contents at sampling point Nos. 10 and 18 in Ribeira dos Covões study site.

\section{Conclusion}

Environmental science and legislation over recent years have supported the view that total content of metals in soil by itself is not a good measure for assessing their bioavailability and not a very useful tool for determining potential risks from soil contamination (review in [21]). Environmental strategies are currently moving towards implementation of risk-based legislative frameworks, and it is possible that the use of a single extraction may not provide a proper assessment of heavy metal forms. It is therefore advisable to combine different extraction methods in order to correctly perform risk-based evaluation.

\section{Acknowledgements}

The authors are grateful to Mr. S. Takemura of Ryukoku University laboratorial work and to Ms. C. Lentfer for English review.

\section{References}

[1] L. M. Gaetke and K. Chow, "Copper toxicity, oxidative stress and antioxidant nutrients," Toxicology, vol. 189, pp. 147-163, 2003.

[2] R. Unterbrunner, M. Puschenreiter, P. Sommer, G. Wieshammer, P. Tlustos, M. Zupan W. W. Wenzel, "Heavy metal accumulation in trees growing on contaminated sites in Central Europe," Environ. Pollut., vol. 148, pp. 107-114, 2007. 
[3] D. Baize and T. Sterckeman, "Of the necessity of knowledge of the natural pedo-geochemical background content in the evaluation of the contamination of soils by trace elements," Sci. Total Environ., vol. 264, no. 1-2, pp. 127-139, 2001.

[4] H. Xue, P. H. Nhat, R. Gachter and P. S. Hooda, "The transport of Cu and $\mathrm{Zn}$ from agricultural soils to surface water in a small catchment," Adv. Environ Res., vol. 8, no. 1, pp. 69-76, 2003.

[5] F. Pinamonti, G. Stringari, F. Gasperi and G. Zorzi, "The use of compost: its effects on heavy metal levels in soil and plants," Res. Cons. \& Recycl., vol. 21, no. 2, pp. 129-143, 1997.

[6] S. Cornu, C. Neal, J. P. Ambrosi, P. Whitehead, M. Neal, J. Sigolo and P. Vachier, "The environmental impact of heavy metals from sewage sludge in ferrasols (Sao Paulo, Brazil)," Sci. Total Environ., vol. 271, pp. 27-48, 2001.

[7] L. Hernandez, A. Probst, J. L. Probst and E. Ulrich, "Heavy metal distribution in some French forest soils: evidence for atmospheric contamination," Sci. Total Environ., vol. 312, no. 1-3, pp. 195-219, 2003.

[8] A. R. Cabral and G. Lefebvre, "Use of sequential extraction in the study of heavy metal retention by silty soils," Water, Air, Soil \& Pollut., vol. 102, pp. 329-344, 1998.

[9] F. A. Veja, E. F. Covelo and M. L. P. Marcet, "Relationships between heavy metals content and soil properties in mine soils," Analy. Chem. Acta, vol. 524, pp. 141-150, 2004.

[10] A. Davis, M. V. Ruby and P.D. Bergstrom, "Factors controlling lead bioavailability in the Butte mining district, Montana," USA - Environ. Geochem. \& Health, vol. 3/4, pp. 147-157, 1994.

[11] J. Li, Z. M. Xie, Y. G. Zhu and R. Naidu, "Risk assessment of heavy metal contaminated soil in the vicinity of a lead/zinc mine," J. Environ. Sci., vol. 6, pp. 881-885, 2005.

[12] N. Sabine, D. M. Brazauskine and D. Rimmer, "Determination of heavy metal mobile forms by different extraction methods," Ekologija, vol. 1, pp. 36-41, 2004

[13] A. M. Ure, "Single extraction schemes for soil analysis and related applications," Sci. Total Environ., vol. 178, pp. 3$10,1996$.

[14] T. Jeannic, "Une nouvelle approche territoriale de la ville," Économie et statistique, vol. 294/295, pp. 25-46, 1996.

[15] A. Piorr, J. Ravetz and I. Tosics, Peri-urbanisation in Europe - towards a European policy to sustain urban-rural futures. Academic Books Life Sciences, Frederiksberg, 2011.

[16] Instituto Nacional de Meteorologia e Geofísica, Anuário climatológico de Portugal. I Parte, Continente, Açores e Madeira-Observações de superfície. Lisboa, 1941-2000.

[17] O. Halonen, H. Tulkki and J. Derome, "Nutrient analysis methods," Metsantutkimuslaitoksen Tiedonantoja, vol. 121, pp. 1-28, 1983.

[18] US Environmental Protection Agency, "Method 3050A - acid digestion of sediments, sludges and soils," Washington DC, 1992.

[19] R. Woodmansee, G. I. Vallis and J. J. Mott, "Grassland Nitrogen," in Terrestrial Nitrogen Cycles: Processes, Ecosystem Strategies and Management Impacts (Ecological Bulletins 33), F. Clark and T. Rosswall eds., Stockholm: Swedish Natural Science Research Council, 1986, pp. 443-46.

[20] R. Witting, H. Neite, "Distribution of lead in the soils of Fagus sylvatica forest in Europe," in Plant and Pollutants in Developed and Developing Countries, M. A. Oztur ed., Izmir: Ege University Press, 1989, pp. 199-206.

[21] E. Meers, R. Samson, F. M. G. Tack, A. Ruttens, M. Vandegehuchte, J. Vangronsveld and M. G. Verloo, "Phytoavailability assessment of heavy metals in soils by single extractions and accumulation by Phaseolus vulgaris," Environ. \& Exp. Bot., vol. 60, pp. 385-396, 2007. 